\title{
ELABORATING PROFESSIONAL QUALIFICATIONS IN UKRAINE: A NEW APPROACH
}

Oleksii Miroshnychenko, Sergii Prytomanov ${ }^{2}$, Rostislav Schokin $^{3}$, Ievgen Romanenko ${ }^{4}$, Oleksandr Datsii ${ }^{5}$

$1 \mathrm{PhD}$ in Economics, Honorary Economist of Ukraine, Executive Vice-president of Confederation of employers of Ukraine, President of Institute of Professional Qualifications http://orcid.org/0000-0001-7184-9560, e-mail: oleksiivm@gmail.com

$2 \mathrm{PhD}$ in Physics and Mathematics on specialty "Theoretical and Mathematical Physics", Associate Professor, Vice-President of "Institute of Professional Qualifications" http://orcid.org/0000-0003-2628-4788, e-mail: psa220855@gmail.com

3 doctor of Law, associate professor, honored worker of physical culture and sports of Ukraine, the President of the Interregional academy of personnel management http://orcid.org/0000-0002-0836-8315, e-mail: rgmaup@gmail.com

4 doctor of Science in public administration, professor, honored lawyer of Ukraine, vicerector of the Interregional academy of personnel management http://orcid.org/0000-0003-2285-0543, e-mail: poboss1978@gmail.com

5 doctor of economic sciences, professor, honored education worker of Ukraine, head of the department of finance, banking and insurance, Interregional academy of personnel management http://orcid.org/0000-0002-7436-3264, e-mail: rvps@ukr.net

\section{Abstract.}

Relevance: aligning competencies for lifelong learning with the requirements of the European Union (EU) makes it necessary to implement new approaches to the development and application of vocational qualifications. They should meet the needs of the labor market and become the basis for the formation and development of the National Qualifications System. All this requires clarification of the conceptual apparatus and methods of improving the existing legal mechanisms for regulating the said process.

Purpose: to substantiate new approach to the development of vocational qualifications in the context of harmonization with modern European approaches.

Methods: theoretical analysis - to study the existing approaches to the development of the National Qualifications System, to identify the main tendencies of this process; comparison and synthesis - to summarize the main scientific approaches to the development of the National Qualifications System and legal mechanisms of its regulation in modern conditions, to analyze its institutional and organizational support; observations and analogies - to substantiate the need for development of a new approach to the application of qualifications in the context of harmonization with European approaches, synthesis and abstraction - to determine the benefits and prerequisites for the implementation of the proposed approach.

The empirical and informative basis of the article is the legal acts of Ukraine on the formation and development of the National Qualifications System, materials of monographs and scientific publications, analytical data, results of own research.

Results: the essential characteristics of the National Qualifications System are revealed, its features and main aspects governing the development of such a system are characterized and the necessary conditions are created to develop a new approach to the application of qualifications in the context of European integration.

Conclusions: the new approach to the application of qualifications is the purposeful formation and development of the National Qualifications System, which should become a tool for lifelong learning, ensuring the quality of learning outcomes, their recognition, and aligning professional qualifications framework in Ukraine with the requirements in EU countries.

Keywords: qualifications, competencies, lifelong learning, national qualifications system, national qualifications framework. 
Introduction. In the context of economic change, challenges posed by globalization and search for a proper place on the world and regional labor markets, it's difficult to predict the relevance, confidence and even name of many modern occupations in Ukraine and in the world. Therefore, in the future, it is especially important not to obtain an occupation, but the competencies that should be obtained during training, improved throughout life and applied in many contexts.

Professional knowledge and skills are of particular importance for sustainable development of the national economy, as imbalance in the ratio of representatives of working occupations and specialists with higher education is approaching 20/80 ratio, which is already a threat to the national security of Ukraine. The Government should take substaintial measures to increase the attractiveness and prestige of working occupations and accelerate the process of modernization of national vocational education and training system. In this context, the role of the National Qualifications System in general and the National Qualifications Framework in particular is updated.

It is known that the National Qualifications Framework is a tool for supporting the development of lifelong learning, as well as development of person career and their employment opportunities (Miroshnychenko, 2017). Under these conditions, the National Qualifications Framework cannot be based only on the educational qualifications that are awarded in the education sphere. Despite the fact that the issue of vocational qualifications in the sphere of development of the National Qualifications Framework in Ukraine has always attracted considerable attention of politicians, researchers, teachers and employers, the proposal to adopt the Laws "On the National Qualifications System" (2009) and "On the System of Professional Qualifications" $(2011,2013)$ was not approved. All this uptades the need for development of the National Qualifications System.

Sources. The works of S. Kalashnikova, R. Kolyshko, L. Korotkova, S. Kravets, V. Kremen, V. Luhovyi, P. Luzan, V. Manko, O. Miroshnychenko, N. Nychkalo, V. Radkevich, V. Savchenko, Zh. Talanova, O. Shcherbak and others are devoted to the problems and prospects of development of the National Qualifications System. The foreign experience of qualifications system development was studied by O. Borodienko, S. Leu, L. Pukhovska, O. Radkevich and others. Formulating theoretical and methodological basis for development of vocational education and training in Ukraine, as well as training of qualified workers in market conditions, which are highlighted in the works of L. Bazyl, L. Yershova, A. Kalenskyi, V. Kruchek, N. Kulalaieva, N. Nychkalo, V. Orlov, M. Pryhodii, V. Radkevich and others, are relevant for today. The modern approaches to the management of career development of specialists are covered in the works of O. Datsii, S. Prytomanov, Ye. Romanenko, H. Shchokin and others. However, despite the existing scientific background, a systematic study of prospects for development of the National Qualifications System that would meet the modern requirements was not properly carried out.

Methods: theoretical analysis - to study the existing approaches to the development of the National Qualifications System, to identify the main tendencies of this process; comparison and synthesis - to summarize the main scientific approaches to the development of the National Qualifications System and legal mechanisms of its regulation in modern conditions, to analyze its institutional and organizational support; observations and analogies to substantiate the need for development of a new approach to the application of qualifications in the context of harmonization with European approaches, synthesis and abstraction - to determine the benefits and prerequisites for the implementation of the proposed approach.

The empirical and informative basis of the article is the legal acts of Ukraine on the formation and development of the National Qualifications System, materials of monographs and scientific publications, analytical data, results of own research.

Purpose of the article - to substantiate new approach to the application of qualifications in the context of harmonization with modern European approaches.

Results and discussion. According to the Council of Europe Proposals, vocational competencies should be relevant to learning outcomes and be up-to-date with key competencies for lifelong learning (Proposal for a Council recommendation on Key Competencies for LifeLong Learning, 2018). Against this background, the special attention should be paid to updating the educational program of general secondary education in the context of introduction of the New Ukrainian School. At the same time, the educational programs should take into account learning outcomes that meet the specified key competencies for lifelong learning. They should contribute to development of the students' conscious attitude towards work and to reflect objectively and fully to both directions of further education and training - academic and vocational.

In addition, given the specific current demographic situation in Ukraine, as well as the need for protection and development of labor potential, the lifelong learning should be a decisive policy in the sphere of education. Under these conditions, it is important to implement a modular approach to the formation and development of competencies, which will provide 
maximum opportunities for all categories of persons who legally seek to realize their potential in the labor market in different contexts.

The need to quickly navigate the rapidly changing world of work updates the importance of effective career counselling, starting with general secondary school and throughout the life of a person: from a graduate of an educational institution - to people aged $45+$. Such career counselling should start with primary school and cover a wide range of stakeholders, including parents. Considering the principle of continuity, the higher education also needs to be significantly reformed. There is a need to review the role of higher educational institutions (HEIs) in preparing specialists for the modern intellectual and high-tech economy. It is also important that higher educational institutions aim to create educational and training clusters as centers of applied science, innovative technologies and startups.

Against this background, the long-term objectives of the National Qualifications Framework include: determining the relations between education and training outcomes, determining the correlation of education and training diplomas and certificates; ensuring the transparency, continuity and comparability of qualifications obtained in different countries or in different education systems; increasing the confidence of consumers of educational services in the qualifications system; ensuring that education and training are consistent with the development of structure and content of professional activity; ensuring the access to lifelong learning to realize professional, economic and personal potential; forming flexible and variable pathways of qualifications, transition from study to work and vice versa due to continuity of educational programs and diplomas/certificates; ensuring the competitiveness and mobility of graduates of educational institutions in the labor markets; promoting the integration of the national education system into the world educational system.

The National Qualifications Framework is an important tool of the personnel training system that ensures: establishment of a system of education and training quality assessment; implementation of the "lifelong learning" strategy, continuity of the obtained learning outcomes within the education system; development of the education and training system; comparison of learning outcomes with systems in other countries; development of industry standards of education, educational programs and qualifications based on competencies; further integration of Ukraine into the global education market; establishment of appropriate structures for recognition of educational and training outcomes.

The need to develop qualifications that meet the needs of the labor market is an incentive to involve employers in the process of development the National Qualifications Framework. These activities resulted in creation of mechanisms to coordinate the process of developing occupational standards and vocational qualifications (sector skills councils for the development of vocational qualifications, specialized non-governmental organizations (eg, Institute of Professional Qualifications). Occupational standards are considered as the basis for the formal recognition of non-formal and informal learning outcomes. The relevant central executive authorities (Ministry of Social Policy of Ukraine, Ministry for Development of Economy, Trade and Agriculture of Ukraine, etc.) contribute to the development of occupational standards and professional qualifications designed to confirm that a person is competent enough to perform relevant functions in the labor market, as well as to expand the system of recognition of the outcomes of non-formal vocational training of persons by working occupations.

The competent authorities and professional associations use internationally recognized qualifications to determine the level of occupational skill of persons. Many of these qualifications are regulated occupations for which educational institutions are not allowed to award qualifications without specific approval from the relevant executive authorities. The regulated occupations are usually governed by relevant regulations other than those of the Ministry of Education and Science of Ukraine, and may also involve professional associations and other authorized entities awarding the qualifications. Based on the information presented, it is obvious that the issue of professional qualifications is wider than the issue of competency-oriented training of future specialists based on occupational standards similar to National Vocational Qualifications (NVQ) and Scottish Vocational Qualifications (SVQ) in the United Kingdom, vocational qualifications in Estonia and national vocational qualifications in Turkey (Radkevich and other, 2018).

However, such qualifications and appropriate independent certification systems for adults are clearly part of the concept that is the subject of this article. That is why the European Training Foundation (ETF) assigned to conduct research of existing or future qualifications outside the current formal education and training system, which addresses the following issues: what is the value of qualifications obtained in the nonformal education system and how can these qualifications be included in the registry of the National Qualifications Framework?

Please note that there are different types of qualifications that can be applied in the development of the National Qualifications System. The criteria for describing such qualifications will help to determine 
which qualifications are "appropriate enough" to be included in the National Qualifications Framework.

Despite the fact that the National Qualifications Framework was approved in 2011, during the first phase of its implementation, which was determined by the Joint Order of the Ministry of Education and Science of Ukraine, Ministry on Youth and Sports of Ukraine and Ministry of Social Policy "On Approval of the Action Plan for Implementation of the National Qualifications Framework" No. 488/225 dated April 20, 2012 (Ministry of Education and Science of Ukraine, Ministry on Youth and Sport of Ukraine, Ministry of Social Policy, 2012), no significant progress has been made by 2015 . However, some innovations have been introduced, in particular: a number of occupational standards and qualifications based on learning outcomes have been developed; the Institute of Professional Qualifications and four sector skills councils for the development of professional qualifications were established; the Resolution of the Cabinet of Ministers of Ukraine "On Approval of the Procedure for Confirmation of the Outcomes of NonFormal Vocational Training of Persons by Work Occupations" No. 340 dated May 15, 2013 (Cabinet of Ministers of Ukraine, 2013) and other legal acts necessary for functioning of the system of validation of non-formal learning outcomes were adopted.

The second stage of implementation of the National Qualifications Framework approved by the Decree of the Cabinet of Ministers of Ukraine No. 1077-p dated December 14, 2016 (Cabinet of Ministers of Ukraine, 2016) covers the period from 2016 to the present and is characterized, in particular, by division of levels of the National Qualifications Framework in the Law of Ukraine "On Higher Education" (Verkhovna Rada of Ukraine. Legislation of Ukraine, 2014), introduction of the National Agency for Higher Education Quality Assurance (Cabinet of Ministers of Ukraine, 2015) and National Agency for Qualifications (Cabinet of Ministers of Ukraine, 2018), determination of certain components of the National Qualifications System in the Law of Ukraine "On Education" (Verkhovna Rada of Ukraine. Legislation of Ukraine, 2017).

The Association Agreement signed between Ukraine and the European Union (Verkhovna Rada of Ukraine. Legislation of Ukraine, 2015) indicated the creation of the National Qualifications Framework that would be in line with the European Qualifications Framework (A Framework for Qualifications of the European Higher Education Area, 2005). The Law of Ukraine "On Education" (Verkhovna Rada of Ukraine. Legislation of Ukraine, 2017) and the Draft Law of Ukraine "On Vocational Education" (Ministry of Education and Science of Ukraine, 2018) contain references to the National Qualifications Framework, but in reality the National Qualifications Framework is still a document that has not yet been systematically applied. Therefore, the National Qualifications Framework does not have a register of qualifications. In practice, people still refer to the existing classifiers of occupations, qualification characteristics, educational programs and state educational standards that are not based on learning outcomes, as well as use existing classes, categories and rates (tariff rates) to describe different skill levels, but not the National Qualifications Framework.

For most Ukrainians, qualification is still associated with a diploma, rather than a level of proven knowledge, skills and abilities that correspond to a certain level of autonomy, responsibility and complexity. The old system was based on a Classifier of occupations and educational programs. The new qualifications system requires that qualifications are based on learning outcomes. It also updates the issue of partial qualifications - as recognition of a part of certain competencies, rather than the occupation as a whole.

The current situation is troubling; the previous system is gradually losing its relevance, and the new system has not yet become functional. The transition from the old system to the new one should be managed gradually. Like the previous qualifications system, the National Qualifications Framework is not only a tool for recognition of formal education, but it also contains a criterion for requirements of the labor market and career development. The new system cannot be based solely on the educational qualifications, but should also extend to other spheres. It also requires the development of an appropriate legal framework to complement the framework existing since 2011.

The current phase of the Action Plan for implementation of the National Qualifications Framework for 2016-2020 involves the development of qualifications of different types (educational standards and programs based on learning outcomes) in accordance with the National Qualifications Framework. The process of reforming the educational standards and programs demonstrates continuous progress, but the work is done by stakeholder groups and without a sufficient level of consistency. In addition, to develop new qualifications based on learning outcomes, which are part of a single framework and listed in the national qualifications register, it is necessary to clearly differentiate the concepts of qualifications, educational standards, educational and vocational programs based on a competence approach; to get acquainted with the description of relevant qualifications, educational and vocational programs, to exchange experience and to agree on further steps. It should also be taken into account that implementation of this approach in the system of vocational, pre-higher and higher education 
is difficult due to the processes of decentralization and autonomy in the management of educational institutions.

The implementation of the National Qualifications Framework will contribute to the development of the National Qualifications System. All stakeholders should focus their efforts on development a national strategy to create an accessible, unified and transparent system of qualifications that can be obtained as a result of the full implementation of the lifelong learning system. Now the terminology for the National Qualifications System seems confusing. Therefore, it is necessary to develop a glossary of concepts to be applied in the lifelong learning system. The concept of the National Qualifications System is under development. Its approval will allow further work on clarifying the qualifications for inclusion in the National Qualifications Framework. As of today, there are no such principles and procedures. According to preliminary estimates, most of the existing qualifications do not meet established international criteria for inclusion in the National Qualifications Framework. It is not surprising, therefore, that Ukrainian vocational qualifications are not recognized at the international level.

Most vocational qualifications lack transparency and relevance. They are not based on occupational standards (OS) and, with some exceptions, are not based on a competence approach (on learning outcomes) to ensure the quality of training.

There is a need to define the role of educational institutions in the development of qualifications, in particular those based on subject area benchmarks.

There is also a contradiction between the current mechanisms of the labor market, the classifier of occupations and realities in enterprises. The National Qualifications Framework is not only a tool for determining qualifications, but also their classifications, and therefore, it is necessary to understand the implications of implementation of the National Qualifications Framework for national and international labor markets. The implications of implementation of the National Qualifications Framework in the classification of occupations should be further analyzed, taking into account different functions of the National Qualifications Framework and the classifier of occupations, as well as the relations existing between them.

The employers complain about the quality of vocational training and until recently had no opportunity to influence this process. The conservatism of the education system leads to the training of specialists who do not fully meet the needs of the labor market. Many occupations are incomprehensible to the employers (for example, typesetting operator, etc.). Many competencies obtained during training are incomprehensible, outdated and inappropriate to the employers. Instead, the ability to apply occupational knowledge and skills in the field of theoretical basics of computer science and practical use of computer technologies, tools and techniques of technical measurements during the design, manufacture, operation and maintenance of technologically advanced equipment and machines (e.g., mechatronics) is required. As a result, a graduate of an educational institution does not understand why he/her is not suitable for the employer and the employer does not satisfy his/her level of training.

The way out of this situation is the proper development of qualifications. Today, qualification characteristics are the basis for determining qualifications. For example, "Farm Worker" (Compilation of Qualification Characteristics, issue 2 "Agriculture and Related Services", 2004) (Ministry of Agrarian Policy of Ukraine, 2004). This issue takes into account the new requirements for the development of qualification characteristics and at the same time it preserves the continuity, traditions of application and features of the previous issues of this Compilation (70 (1984), 62 (1985), 00 (1986, 1990)). Standard WageRates and Skills Reference Book, "Industry Qualification Characteristics of the Positions of Leaders and Specialists of the System of the USSR State Committee on Agriculture" (1987)".

Let's consider this on the example of a farm worker (Table 1).

The task of the VET school is to create the conditions for a person to acquire relevant occupational knowledge and skills. There are many situations when the educational program does not meet the requirements of employers.

The Fig. 1 shows a graphic structure of vocational competencies of skilled farm workers (as of today).

Table 1

Qualification characteristics of a farm worker

\begin{tabular}{ll} 
Types of characteristics & Description \\
\hline Qualification & 4th category \\
\hline Task & $\begin{array}{l}\text { Performs manual and partially automated works } \\
\text { on care for cows and other cattle }\end{array}$ \\
\hline Duties & $\begin{array}{l}\text { Feeding and grazing animals and poultry. } \\
\text { Milking cows. Manure cleaning, room cleaning }\end{array}$ \\
\hline
\end{tabular}



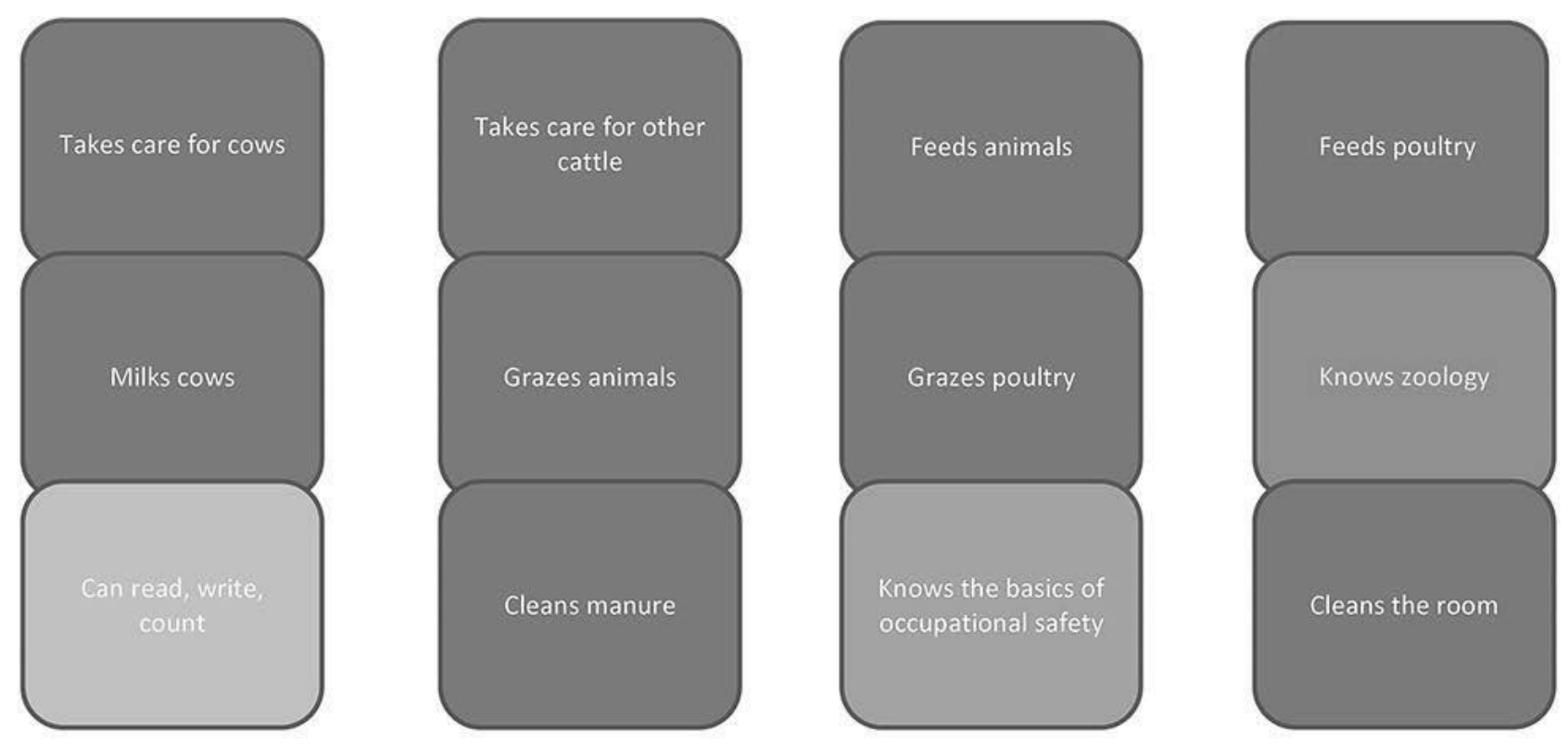

Fig. 1. Vocational competencies of the farm worker in accordance with the current qualification

Instead, a new approach to the development of qualifications through vocational competencies consists in the development of four types of vocational competencies: basic, mandatory, specific and recommended (Fig. 2). This division is closely linked to the classification of economic sectors and is that there is a certain part of universal vocational competencies within one (or several related) economic sectors. These competencies can be called "Mandatory Competencies". According to the above example, they can be referred to as: "the ability to comply with the occupational safety and health rules", "the ability to handle livestock", "the ability to apply the knowledge and basics of zoology and plant production" and others. The category "Basic" includes a set of competencies that are necessary for any work activity, as well as for the socialization of the individual in the team and society (ability to read, write, understand assignments, work in a team, etc.).

"Specific", within a certain type of economic sector, means vocational competencies specific to particular types of work, such as: "The ability to feed chickens", "The ability to care for cattle", etc. "Recommended" vocational competencies can be added to basic vocational competencies on the recommendations (wishes) of the employers. To do this, the employers turn to the educational institutions with the proposal to train certain vocational competencies related to the specific equipment, technological production, etc. Each type of competency has a corresponding "credit value", i.e. the number of hours required to acquire theoretical knowledge and practical skills, taking into account pre-determined learning outcomes and methods (tools) of their assessment.
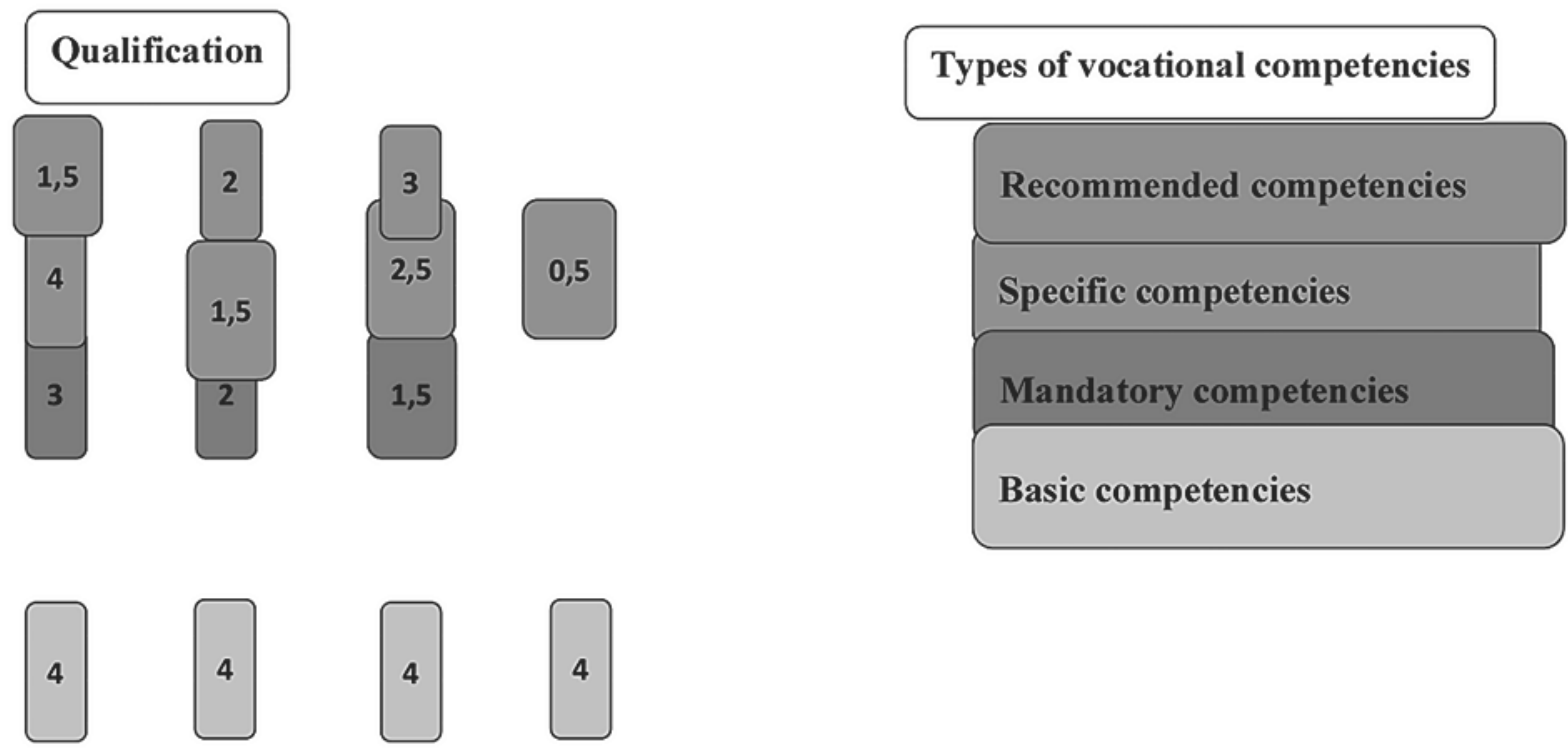

Fig. 2. Vocational competencies of the farm worker in accordance with the new qualification 
Vocational competency is an agreed set of learning outcomes and related assessment criteria, and may look like this. Let's consider the learning outcomes and assessment criteria for vocational competency "The ability to feed animals" (Table 2). This competency corresponds to Level 3 of the National Qualifications Framework and can be approximately learned in 12 hours ( 0.5 credits).

Provided that there is an adequate number of vocational competencies described in this way, which should be developed by the authorized entities and kept in a relevant register, it is easy enough to compose new vocational qualifications other than standard ones. For example, we need to train a farm worker to grow vegetables (Fig. 3). We see that in the current set of vocational competencies there is no ones demanded from the employer (in the figure the corresponding competencies are indicated in yellow). However, the register of qualifications contains vocational competencies related to the vegetable growing, which are easily integrated into the required set of vocational competencies of a farm worker, either by increasing the number of hours or by replacing some competencies (as agreed by the employer and the applicant).

This approach to the formation of qualifications through a standardized set of vocational competencies meets the requirements of the European Classification of Skills, Competencies, Qualifications and Occupations (ESCO), according to which skills, competencies, qualifications and occupations are defined and classified (ESCO Service Platform Technical documentation, 2017). A similar approach to the formation of qualifications is applied in the USA, Australia, Canada and New Zealand. The example is O'Net - the largest qualification resource of the Western hemisphere developed with the assistance of the US Department of Labor, Employment and

Table 2

Vocational competency "The ability to feed animals"

Learning outcomes

Person will be able to:

Feed animals
Assessment criteria

Person can:

1. Properly determine the required food and its quantity for different animal species

2. Choose the right tool for different types of feeding

3. Know the features of marking the types of feed for different animal species

Work safely

1. To carry out sanitary treatment of the equipment, tools, to maintain its proper sanitary condition

2. To observe occupational safety and health rules and animal feeding requirements

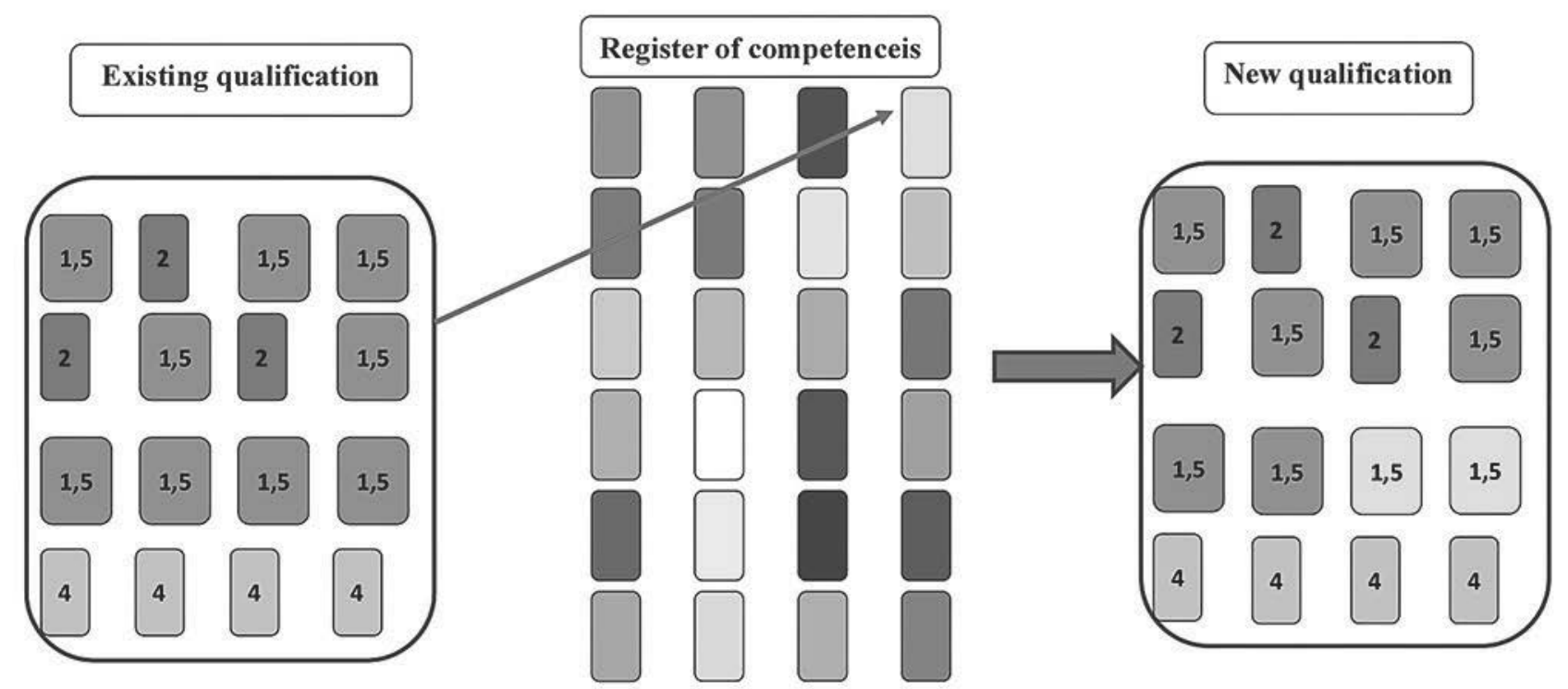

Fig. 3. Vocational competencies in accordance with existing and new qualifications systems 
Training (USDOL/ETA), which is the main source of vocational qualifications ( $\left.\mathrm{O}^{\prime} \mathrm{Net}, 2020\right)$. This resource provides the up-to-date information for further development of skilled workforce training programs. The core of the project is a database containing standardized descriptions of more than a thousand occupations from different industries.

Conclusions. Therefore, in order to provide mechanisms for updating qualifications and harmonizing them with the modern European instruments defined by the Association Agreement between Ukraine and the European Union (2015) and the European Qualifications Framework (2005), it is appropriate to apply a new approach to the development of qualifications through standardized sets of vocational competencies. Unlike the existing approach, it is proposed to develop different vocational qualifications using vocational competencies differentiated by four types (basic, mandatory, specific and recommended). This division is universal for professional activities and closely linked to the modern classification of economic activities, which was not the case when applying the existing approach.

The likely effects of applying the new approach include: accelerating the educational program development; saving money for training and advanced training of teachers and job training instructors; accelerating the entry of a person into the labor market; the possibility of organizing training on the acquisition of new modules using different forms of training (including e-learning).

The implementation of this approach will allow creating a platform for: joint development of new qualifications by the employers, representatives of vocational schools and other stakeholders; improvement of occupational standards and standards of assessment; development of new certified agencies for vocational education quality assurance in order to coordinate the processes of development of qualifications and accreditation of educational programs.

\section{List of references}

Верховна Рада України. Законодавство України, 2014а. Закон України "Про вищу освіту" від 1 липня 2014 р. № 1556-VII. [online] (Останнє оновлення 18 Березень 2020) Доступно: <https://zakon.rada.gov.ua/laws/show/1556$18>$ [Дата звернення 30 Березень 2020].

Верховна Рада України. Законодавство України, 2014b. Закон України "Про ратифікацію Угоди про асоціацію між Україною, з однієї сторони, та Свропейським Союзом, Свропейським співтовариством з атомної енергії і їхніми державами-членами, з іншої сторони" від 16 вересня 2014 року № 1678-VII. [online] (Останнє оновлення 27 Вересень 2014) Доступно: <https://zakon.rada.gov.ua/laws/show/984_011> [Дата звернення 20 Лютий 2020].

Верховна Рада України. Законодавство України, 2017. Закон України "Про освіту" від 5 вересня 2017 року № 2145-VIII. [online] (Останнє оновлення 02 квітня 2020) Доступно: <https://zakon.rada.gov.ua/laws/show/2145-19> [Дата звернення 25 Березень 2020].

Кабінет Міністрів України, 2018. Постанова "Деякі питання Національного агентства кваліфікацій" від 5 грудня 2018 р. № 1029. [online] (Останнє оновлення 14 серпня 2019) Доступно: <https://zakon.rada.gov.ua/laws/show/ 1029-2018-п> [Дата звернення 19 Січень 2020].

Кабінет Міністрів України, 2011. Постанова "Про затвердження Національної рамки кваліфікацій" від 23 листопада 2011 р. № 1341. [online] (Останнє оновлення 25 червня 2019) Доступно: <https://zakon.rada.gov.ua/laws/ show/1341-2011-п> [Дата звернення 10 Березень 2020].

Кабінет Міністрів України, 2013. Постанова "Про затвердження Порядку підтвердження результатів неформального професійного навчання осіб за робітничими професіями" від 15 травня 2013 р. № 340 [online] (Ocтаннє оновлення 12 Березень 2020) Доступно: <https://zakon.rada.gov.ua/laws/show/340-2013-п> [Дата звернення 28 Ciчень 2020].

Кабінет Міністрів України, 2015. Постанова "Про утворення Національного агентства із забезпечення якості вищої освіти" від 15 квітня 2015 р. № 244. [online] (Останнє оновлення 28 серпня 2019) Доступно: <https:// zakon.rada.gov.ua/laws/show/244-2015-п> [Дата звернення 05 Лютий 2020].

Кабінет Міністрів України, 2016. Розпорядження "Про затвердження плану заходів із впровадження Національної рамки кваліфікацій на 2016-2020 роки" від 14 грудня 2016 р. № 1077-p. [online] (Останнє оновлення 14 Грудень 2016) Доступно: <https://zakon.rada.gov.ua/laws/show/1077-2016-p> [Дата звернення 15 Січень 2020].

Міністерство аграрної політики України, 2004. Довідник кваліфікаційних характеристик професій працівників. Вип. 2. Сільське господарство та пов'язані з ним послуги. [online] (Останнє оновлення 7 Червень 2004) Доступно: $<$ https://ips.ligazakon.net/document/view/fin11381?an=4\&ed=2004_06_07> [Дата звернення 18 Січень 2020].

Міністерство освіти і науки, молоді та спорту України, Міністерство соціальної політики, 2012. Наказ "Про затвердження Плану заходів щодо впровадження Національної рамки кваліфікацій" від 20.04.2012 р. № 488/225. [online] (Останнє оновлення 20 квітня 2012) Доступно: <http://ipq.org.ua/upload/files/files/06 Biblioteka/ 01 Normativna_baza/02_Vprovadzhennja_Nacionalnoi_ramki_kvalifikacii/0 4 Nakazi/ 2012.04.20_488_225_MINSOCPOLITIKI_MONMOLOD̄SPORTU.pdf $>$ [Дата звернення 10 Лютий $202 \overline{0}$ ].

Міністерство освіти і науки України, 2018. Проект Закону України "Про професійну (професійно-технічну) освіту". [online] (Останнє оновлення 10 Лютий 2020) Доступно: $<$ https://mon.gov.ua/ua/news/mon-proponuye-dogromadskogo-obgovorennya-proekt-zakonu-ukrayini-pro-profesijnu-profesijno-tehnichnu-osvitu> [Дата звернення 27 Лютий 2020]. 
Мірошниченко, О.В., 2017. Щоб запрацювала Національна рамка кваліфікацій, вона повинна бути прямо зв'язаною з системою оплати праці! [online] Доступно: <http://employers.org.ua/news/id1672> [Дата звернення 12 Лютий 2020].

Ничкало, Н.Г., 2018. Перспективи розвитку освіти дорослих в Україні (післямова). В: Концептуальні засади розвитку освіти дорослих: світовий досвід, українські реалії і перспективи. Київ: Знання України, с. $602-606$.

Пуховська, Л. П., Ворначев, А. О., Мельник та С. В., Кравець, Ю. І., 2014. Професійні стандарти і кваліфікації у країнах з високорозвинутою економікою. Київ: Поліграфсервіс.

Радкевич, В.О., 2016. Теоретичні та методичні засади розвитку професійної освіти і навчання: результати, проблеми, перспективи. Науковий вісник Інституту професійно-технічної освіти НАПН України. Професійна педагогіка, 11, с. 5-22.

Радкевич, В. О., Пуховська, Л. П., Бородієнко, О. В. та ін., 2018. Сучасні моделі професійної освіти і навчання в країнах Свропейського Союзу: порівняльний досвід. Житомир: Полісся.

A Framework for Qualifications of the European Higher Education Area, 2005. The report by the Bologna Working Group on Qualifications Frameworks, February. [online] Available at: <http://eacea.ec.europa.eu/Education/eurydice/ documents/thematic_reports/138EN.pdf> [Accessed 15 April 2020].

ESCO Service Platform - Technical documentation, 2017. European Skills, Competences, Qualifications and Occupations. [online] Available at: $<$ https://ec.europa.eu/esco/portal/home $>$ [Accessed 15 April 2020].

O'Net Analyst Ratings of Occupational Skills: Analysis Cycle 20 Results, 2020. O'Net Resource center. [online] Available at: $<$ https://www.onetcenter.org/> [Accessed 15 April 2020].

Proposal for a Council recommendation on Key Competences for LifeLong Learning, 2018. Text with EEA relevance. Brussels: European Commission. [online] Available at: $<$ https://eur-lex.europa.eu/resource.html?uri=cellar:395443f6-fb6d11e7-b8f5-01aa75ed71a1.0001.02/DOC_1\&format=PDF $>$ [Accessed 15 April 2020].

\section{Translation \& Transliteration}

Verkhovna Rada Ukrainy. Zakonodavstvo Ukrainy [Verkhovna Rada of Ukraine. Legislation of Ukraine], 2014a. Zakon Ukrainy "Pro vyshchu osvitu" vid 1 lypnia 2014 r. № 1556-VII [Law of Ukraine "On Higher Education" of July 1, 2014 No. 1556-VII]. [online] (Ostannie onovlennia 18 Berezen 2020) Dostupno: <https://zakon.rada.gov.ua/laws/show/ 1556-18> [Data zvernennia 30 Berezen 2020], [in Ukrainian].

Verkhovna Rada Ukrainy. Zakonodavstvo Ukrainy [Verkhovna Rada of Ukraine. Legislation of Ukraine], 2014b. Zakon Ukrainy "Pro ratyfikatsiiu Uhody pro asotsiatsiiu mizh Ukrainoiu, z odniiei storony, ta Yevropeiskym Soiuzom, Yevropeiskym spivtovarystvom z atomnoi enerhii i yikhnimy derzhavamy-chlenamy, $z$ inshoi storony" vid 16 veresnia 2014 roku № 1678-VII [Law of Ukraine "On ratification of the Association Agreement between Ukraine, of the one part, and the European Union, the European Atomic Energy Community and their Member States, of the other part" of September 16, 2014 No. 1678-VII]. [online] (Ostannie onovlennia 27 veresnia 2014) Dostupno: <https://zakon.rada.gov.ua/laws/ show/984_011> [Data zvernennia 20 Liutyi 2020], [in Ukrainian].

Verkhovna Rada Ukrainy. Zakonodavstvo Ukrainy [Verkhovna Rada of Ukraine. Legislation of Ukraine], 2017. Zakon Ukrainy "Pro osvitu" vid 5 veresnia 2017 roku № 2145-VIII [Law of Ukraine "On Education" of September 5, 2017 No. 2145-VIII]. [online] (Ostannie onovlennia 02 Kviten 2020) Dostupno: <https://zakon.rada.gov.ua/laws/show/2145-19> [Data zvernennia 25 Berezen 2020], [in Ukrainian].

Kabinet Ministriv Ukrainy [Cabinet of Ministers of Ukraine], 2018. Postanova "Deiaki pytannia Natsionalnoho ahentstva kvalifikatsii" vid 5 hrudnia 2018 r. № 1029 [Decree "Some Issues of the National Qualifications Agency" of December 5, 2018 No. 1029]. [online] (Ostannie onovlennia 14 serpnia 2019) Dostupno: <https://zakon.rada.gov.ua/ laws/show/1029-2018-p> [Data zvernennia 19 Sichen 2020], [in Ukrainian].

Kabinet Ministriv Ukrainy [Cabinet of Ministers of Ukraine], 2011. Postanova "Pro zatverdzhennia Natsionalnoi ramky kvalifikatsii" vid 23 lystopada 2011 r. No. 1341 [Decree "On approval of the National Qualifications Framework" of November 13, 2011 No. 1341]. [online] (Ostannie onovlennia 25 Chervnia 2019) Dostupno: <https://zakon.rada.gov.ua/ laws/show/1341-2011-p> [Data zvernennia 10 Berezen 2020], [in Ukrainian].

Kabinet Ministriv Ukrainy [Cabinet of Ministers of Ukraine], 2013. Postanova "Pro zatverdzhennia Poriadku pidtverdzhennia rezultativ neformalnoho profesiinoho navchannia osib za robitnychymy profesiiamy" vid 15 travnia 2013 r. № 340 [Decree "On Approval of the Procedure for Confirmation of the Results of Non-Formal Professional Training of Persons by Work Occupations" of May 15, 2013 No. 340]. [online] (Ostannie onovlennia 12 bereznia 2020) Dostupno: $<$ https://zakon.rada.gov.ua/laws/show/340-2013-p > [Data zvernennia 28 Sichen 2020], [in Ukrainian].

Kabinet Ministriv Ukrainy [Cabinet of Ministers of Ukraine], 2015. Postanova "Pro utvorennia Natsionalnoho ahentstva iz zabezpechennia yakosti vyshchoi osvity" vid 15 kvitnia 2015 r. № 244 [Decree "On Establishment of the National Agency for Quality Assurance in Higher Education" of April 24, 2015 No. 244]. [online] (Ostannie onovlennia 28 serpnia 2019) Dostupno: <https://zakon.rada.gov.ua/laws/show/244-2015-p> [Data zvernennia 05 Liutyi 2020], [in Ukrainian].

Kabinet Ministriv Ukrainy [Cabinet of Ministers of Ukraine], 2016. Rozporiadzhennia "Pro zatverdzhennia planu zakhodiv iz vprovadzhennia Natsionalnoi ramky kvalifikatsii na 2016-2020 roky" vid 14 hrudnia 2016 r. № 1077-r. [Ordinance "On Approval of the Action Plan for Implementation of the National Qualifications Framework for 20162020" of December 14, 2016 No. 1077-p.]. [online] (Ostannie onovlennia 14 Gruden 2016) Dostupno: <https:// zakon.rada.gov.ua/laws/show/1077-2016-r> [Data zvernennia 15 Sichen 2020], [in Ukrainian].

Ministerstvo ahrarnoi polityky Ukrainy [Ministry of Agrarian Policy of Ukraine], 2004. Довідник кваліфікаиійних характеристик професій прачівників. Вип. 2. Сільське господарство та пов'язані з ним послуги. [Напdbоok оf qualification characteristics of professions of workers. No. 2. Agriculture and related services]. [online] (Ostannie onovlennia 7 chervnia 2004) Dostupno: $<$ https://ips.ligazakon.net/document/view/fin11381?an=4\&ed=2004_06_07 $>$ [Data zvernennia 18 Sichen 2020], [in Ukrainian]. 
Ministerstvo osvity i nauky, molodi ta sportu Ukrainy, Ministerstvo sotsialnoi polityky [Ministry of Education and Science, Youth and Sport of Ukraine, Ministry of Social Policy], 2012. Nakaz "Pro zatverdzhennia Planu zakhodiv shchodo vprovadzhennia Natsionalnoi ramky kvalifikatsii" vid 20.04.2012 r. № 488/225 [Order "On approval of the Action Plan for the implementation of the National Qualifications Framework" of 20.04.2012 No. 488/225]. [online] (Ostannie onovlennia 20 Kviten 2012) Dostupno: <http://ipq.org.ua/upload/files/files/06 Biblioteka/01 Normativna baza/ 02 Vprovadzhennja Nacionalnoi_ramki_kvalifikacii/04_Nakazi/2012.04.20_488_225_MINSOCPOLITIKI_ MŌNMOLODSPORTÜ.pdf $>$ [Data zvernennia 10 Liutyi 2020], [in Ukrainian].

Ministerstvo osvity i nauky [Ministry of Education and Science of Ukraine], 2018. Proekt Zakonu Ukrainy "Pro profesiinu (profesiino-tekhnichnu) osvitu" [Draft Law of Ukraine "On Vocational (Vocational) Education"]. [online] (Ostannie onovlennia 10 liutoho 2020) Dostupno: <https://mon.gov.ua/ua/news/mon-proponuye-do-gromadskogoobgovorennya-proekt-zakonu-ukrayini-pro-profesijnu-profesijno-tehnichnu-osvitu> [Data zvernennia 27 Liutyi 2020], [in Ukrainian].

Miroshnichenko, O.V., 2017. Shchob zapratsiuvala Natsionalna ramka kvalifikatsii, vona povynna buty priamo zviazanoiu z systemoiu oplaty pratsi! [In order for the National Qualifications Framework to work, it must be directly linked to the pay system!]. [online] Dostupno: <http://employers.org.ua/news/id1672> [Data zvernennia 12 Liutyi 2020], [in Ukrainian].

Nichkalo, N.G., 2018. Perspektyvy rozvytku osvity doroslykh v Ukraini (pisliamova). Kontseptualni zasady rozvytku osvity doroslykh: svitovyi dosvid, ukrainski realii i perspektyvy. [Prospects for the development of adult education in Ukraine (afterword). Conceptual principles of adult education development: world experience, Ukrainian realities and perspectives]. Zb. nauk. statei [kol. avtoriv]. Kyiv: Znannia Ukrainy, s. 602-606, [in Ukrainian].

Puhovska, L.P., Vornachev, A.O., Melnyk, S.V., Kravets, Y.I., 2014. Profesiini standarty i kvalifikatsii u krainakh z vysokorozvynutoiu ekonomikoiu [Professional standards and qualifications in countries with highly developed economies]. Kyiv: NVP Polihrafservis, [in Ukrainian].

Radkevich, V.O., 2016. Teoretychni ta metodychni zasady rozvytku profesiinoi osvity i navchannia: rezultaty, problemy, perspektyvy [Theoretical and methodological foundations of the development of vocational education and training: results, problems, perspectives]. Naukovyi visnyk Instytutu profesiino-tekhnichnoi osvity NAPN Ukrainy. Profesiina pedahohika [Scientific Bulletin of the Institute of Vocational Education of the National Academy of Pedagogical Sciences of Ukraine. Professional Pedagogy], 11, s. 5-22, [in Ukrainian].

Radkevych, V. O., Pukhovska, L. P., Borodiienko, O. V. ta in., 2018. Suchasni modeli profesiinoi osvity i navchannia $v$ krainakh Yevropeiskoho Soiuzu: porivnialnyi dosvid [Current Models of Vocational Education and Training in the European Union: A Comparative Experience], Zhytomyr, Polissya, [in Ukrainian].

A Framework for Qualifications of the European Higher Education Area, 2005. The report by the Bologna Working Group on Qualifications Frameworks, February. [online] Available at: <http://eacea.ec.europa.eu/Education/eurydice/ documents/thematic_reports/138EN.pdf $>$ [Data zvernennia 10 liutyi 2020], [in English].

ESCO Service Platform - Technical documentation, 2017. European Skills, Competences, Qualifications and Occupations. [online] Available at: <https://ec.europa.eu/esco/portal/home $>$ [Data zvernennia 05 Liutyi 2020], [in English].

O'Net Analyst Ratings of Occupational Skills: Analysis Cycle 20 Results, 2020. O'Net Resource center. [online] Available at: <https:/www.onetcenter.org/> [Data zvernennia 12 Liutyi 2020], [in English].

Proposal for a Council recommendation on Key Competences for LifeLong Learning, 2018. Text with EEA relevance, Brussels: European Commission. [online] Available at: <https://eur-lex.europa.eu/resource.html?uri=cellar:395443f6fb6d-11e7-b8f5-01aa75ed71a1.0001.02/DOC_1\&format=PDF> [Data zvernennia 14 Liutyi 2020], [in English]. 


\section{Формування професійних кваліфікацій в Україні: новий підхід}

\section{Олексій Мірошниченко ${ }^{1}$, Сергій Притоманов $^{2}$, Ростислав Щокін $^{3}$, Свген Романенко $^{4}$, Олександр Дацій $^{5}$}

1 кандидат економічних наук, заслужений економіст України, виконавчий віце-президент Конфедерації роботодавців України, президент Інституту професійних кваліфікацій

2 кандидат фізико-математичних наук,віце-президент Інституту професійних кваліфікацій

3 доктор юридичних наук, доцент, заслужений працівник фізкультури та спорту України, президент Міжрегіональної академії управління персоналом

4 доктор наук з державного управління, професор, заслужений юрист України, проректор з наукової роботи Міжрегіональної академії управління персоналом

5 доктор економічних наук, професор, заслужений працівник освіти України, завідувач кафедри фінансів, банківської та страхової справи Міжрегіональної академії управління персоналом

\section{Реферат.}

Актуальність. Приведення компетентностей для навчання впродовж життя у відповідність до вимог Свропейського Союзу (СС) зумовлює необхідність запровадження нових підходів до розроблення та застосування професійних кваліфікацій. Вони мають відповідати потребам ринку праці та стати основою формування та розвитку Національної системи кваліфікацій. Все це потребує уточнення поняттєво-термінологічного апарату та методик вдосконалення існуючих нормативно-правових механізмів регулювання означеного процесу.

Mета: здійснити наукове обгрунтування нового підходу до формування професійних кваліфікацій в контексті гармонізації з сучасним європейським інструментарієм.

Методи: теоретичного аналізу - для дослідження існуючих підходів до формування Національної системи кваліфікацій, визначення основних тенденцій ії розвитку; порівняння та синтезу - для узагальнення основних наукових підходів до розвитку Національної системи кваліфікацій та нормативно-правового механізму їі регулювання в сучасних умовах, здійснення аналізу іiі інституційно-організаційного забезпечення; спостереження та аналогії - для обгрунтування необхідності розроблення нового підходу до застосування кваліфікацій в контексті гармонізації $з$ європейськими принципами, синтезу та абстрагування - для визначення переваг та передумов реалізації запропонованого підходу. Емпіричну й інформаційну основу статті становлять нормативно-правові акти України 3 питань формування та розвитку Національної системи кваліфікацій, матеріали монографій та наукових публікацій, аналітичні дані, результати власних проведених досліджень.

Результати: розкрито істотні характеристики Національної системи кваліфікацій, охарактеризовано її особливості та основні аспекти, що регулюють розвиток такої системи та створюють належні умови для формування нового підходу застосування кваліфікацій в контексті європейської інтеграції.

Висновки: за допомогою нового підходу застосування кваліфікацій відбувається цілеспрямоване формування та розвиток Національної системи кваліфікацій, яка має стати інструментом навчання впродовж життя, забезпечення якості результатів навчання, їх визнання, а також приведення у відповідність українських кваліфікацій до вимог у країнах СС.

Ключові слова: кваліфікаџії, компетентності, навчання впродовж життя, національна система кваліфікацій, начіональна рамка кваліфікаџій. 